\begin{tabular}{|l|l|}
\hline JURNAL ABDI MASYA & Volume 1 No 2 \\
Mei 2021 \\
E-ISSN : 2774-2849 & Pp 66-71 \\
P-ISSN : 2774-2881 & Website : https://jurnal.sttw.ac.id/index.php/abma/about \\
\hline
\end{tabular}

\title{
Peningkatan Kompetensi Desain Bagi Guru SMK Menggunakan Software Solidworks
}

\section{DESIGN COMPETENCY IMPROVEMENT FOR VOCATIONAL SCHOOL TEACHERS USING SOLIDWORKS SOFTWARE}

\author{
Agus Jamaldi ${ }^{1 *}$, Agung Supriyanto ${ }^{2}$, Deni Andriyansyah ${ }^{3}$, Muh. Tsaqila \\ Wicaksono ${ }^{4}$, Albert Yunatan Savidaprima ${ }^{5}$, Tri Widodo Besar Riyadi ${ }^{6}$ \\ 1,2,3,4,5 Program Studi Teknik Mesin, Sekolah Tinggi Teknologi Warga, Surakarta, Indonesia \\ ${ }^{6}$ Program Studi Teknik Mesin, Universitas Muhammadiyah Surakarta \\ *E-mail: agus.jamaldi@gmail.com
}

\begin{abstract}
ABSTRAK
Program Kemitraan Masyarakat (PkM) ini bertujuan untuk meningkatkan kompetensi guru SMK khususnya dalam bidang desain menggunakan software Solidworks. Guru yang merupakan subjek utama dalam transfer pengetahuan ini harus memiliki kompetensi yang memadahi, sehingga ilmu yang ditransfer kepada para siswa dapat dimengerti dengan baik. Kegiatan ini dilaksanakan mengingat adanya tuntutan perkembangan zaman dalam bidang desain, di mana desain saat ini diharapkan mampu dikerjakan secara efisien, hasil yang akurat, dan mampu dilakukan perbaikan dalam waktu singkat jika terjadi kesalahan. Metode pelatihan dengan cara para peserta mengikuti langkah-langkah tutorial dari instruktur. Materi pelatihan dirangkum dalam modul pelatihan yang diberikan kepada setiap peserta serta diakhir sesi, semua peserta wajib mengisi form post-test yang telah disediakan. Hasil dari pelatihan dan analisis terhadap jawaban post-test peserta didapatkan bahwa kemampuan para peserta dalam menggunakan Solidworks meningkat sebesar 33\%. Pelatihan ini juga sangat bermanfaat dalam meningkatkan kompetensi/kemampuan para guru SMK khususnya di bidang desain menggunakan software SolidWorks serta diharapkan kompetensi yang sudah diperoleh dapat ditransfer ke para siswanya.
\end{abstract}

Kata Kunci : Desain, Guru, SolidWorks.

\section{ABSTRACT}

This Community Partnership Program (PKM) aims to improve the competence of SMK teachers, especially in the field of design using Solidworks software. Teachers who are the main subject in this knowledge transfer must have adequate competence so that the knowledge transferred to students can be understood properly. This activity is carried out considering the demands of the times in the field of design, where current designs are expected to be able to be done efficiently, with accurate results, and to be able to be repaired in a short time if something goes wrong. The training method is where the participants follow the tutorial steps of the instructor. The training material was summarized in the training module given to each participant and at the end of the session, all participants must fill out the post-test form provided. The results of the training and analysis of the participants 'post-test answers showed that the participants' ability to use Solidworks increased by 33\%. This training was also very useful in improving the competencelability of vocational school teachers, especially in the field of design using SolidWorks software and it was hoped that the competencies that have been obtained can be transferred to students.

Keyword: Design, teachers, SolidWorks

Submit : 25 Maret 2021 Revision : 30 April 2021 Accepted: 3 Mei 2021

Published : 28 Mei 2021 


\section{PENDAHULUAN}

Melalui Kementerian Pendidikan dan Kebudayaan, pemerintah Indonesia mencanangkan beberapa program, salah satu dari program-program tersebut adalah Sekolah Menengah Kejuruan (SMK) BISA. Dengan adanya program "SMK BISA" diharapkan dapat menciptakan lulusan SMK dengan kualitas yang unggul, sehingga siap dan mampu terjun ke dunia kerja yang sesungguhnya. Untuk mencapai tujuan ini maka diperlukan sumber daya manusia (SDM) khususnya para guru yang memiliki kompetensi yang unggul pula dalam bidangnya.

Berdasarkan Permendikbud no. 34 tahun 2018 disebutkan SMK adalah pendidikan formal pada jenjang pendidikan menengah yang menyelenggarakan program kejuruan (Permendikbud No. 34/2018 Tentang Standar Nasional Pendidikan SMK/MAK, 2018). Undang-undang no. 14 tahun 2005 tentang Guru dan Dosen mengamanatkan bahwa guru SMK/MAK harus memiliki kualifikasi akademik, kompetensi, dan sertifikat pendidik [1]. Kualifikasi akademik guru merupakan tingkat pendidikan minimal yang harus dipenuhi yang dibuktikan dengan ijazah. Kompetensi guru pada umumnya mencakup 4 (empat) kompetensi, yaitu kompetensi pedagogik, kepribadian, sosial, dan profesional. Kompetensi keahlian di bidang kejuruan yang merupakan kompetensi profesional, dibuktikan dengan sertifikat keahlian yang relevan sesuai ketentuan peraturan perundang-undangan.

Berfokus pada kompetensi profesional dan mengacu dari lampiran V Permendikbud no. 34 tahun 2018 [2], bahwa yang dimaksud dengan kompetensi profesional adalah kemampuan guru dalam menguasai pengetahuan bidang ilmu pengetahuan, teknologi, dan/atau seni dan budaya yang diampunya yang sekurang-kurangnya meliputi penguasaan materi pembelajaran secara luas dan mendalam sesuai dengan standar isi program satuan pendidikan, mata pelajaran, dan/atau kelompok mata pelajaran yang akan diampu, dan penguasaan konsep dan metode disiplin keilmuan, teknologi, atau seni yang relevan, yang secara konseptual menaungi atau koheren dengan program satuan pendidikan, mata pelajaran, dan/atau kelompok mata pelajaran yang akan diampu [3].

Saat ini kemajuan teknologi desain sangat cepat dan memiliki keunggulan yang sangat bervariasi. Sebagai seorang pengajar, dalam hal ini adalah guru SMK menyadari perlunya penyesuaian kompetensi-kompetensi yang harus selalu ditingkatkan yang nantinya akan ditransfer kepada anak didiknya. Namun dalam kenyataannya terdapat beberapa kendala yang sering dihadapi oleh para guru karena masih kurangnya software dan instruktur profesional [4]. Dengan demikian proses pembelajaran belum bisa maksimal. Sebagaimana diketahui bersama bahwa kebutuhan guru profesional yang mengajar di SMK merupakan hal yang tidak bisa dipungkiri, seiring dengan tuntutan revolusi industri 4.0 saat ini, di mana hampir disemua aspek dituntut untuk bermigrasi ke digitalisasi . Dalam bidang gambar juga tidak bisa terlepas dari tuntutan ini. Semakin banyak software-software desain yang memberikan kelebihan masing-masing. Dilihat dari sudut pandang industri saat ini, dalam mendesain para desainer diwajibkan memiliki kemampuan menggunakan software desain dalam pekerjaannya. Solidworks merupakan salah satu software desain yang banyak digunakan pada industri. Kendala saat ini yang terjadi adalah tidak semua sekolah memiliki software Solidworks untuk pembelajaran desain. Hal ini juga menjadi kendala bagi para guru untuk melatih skill dan meningkatkan kompetensinya dalam mendesain. Solusi yang dapat diambil oleh para guru adalah dengan cara mengikuti pelatihan/workshop yang diselenggarakan oleh pihak dari luar sekolah. Dengan mengikuti pelatihan/workshop maka para guru mampu meningkatkan kompetensinya dan memiliki pengalaman baru yang bersumber dari instruktur-instruktur profesional [5].

Mengacu dari jabaran tersebut di atas, maka setiap guru SMK dituntut agar "melek" dengan kemajuan teknologi saat ini. Berdasarkan hal ini, maka PkM ini dilaksanakan dalam bentuk pelatihan bagi guru-guru SMK khususnya dalam bidang desain menggunakan Solidworks. Adapun tujuan pelatihan ini adalah untuk mentransfer ilmu pengetahuan serta memberikan pemahaman dan pengalaman yang lebih bagi guru-guru SMK khususnya terkait penggunaan software Solidworks untuk keperluan desain dan 
analisis yang nantinya dapat diterapkan/disampaikan kepada para siswa di sekolah masingmasing.

\section{METODE}

PKM ini dilaksanakan di laboratorium CAD S1 Teknik Mesin STT Warga dengan memberikan pelatihan desain menggunakan software SolidWorks. Pelatihan dilaksanakan dengan metode demonstrasi atau tutorial oleh instruktur. Para peserta diberikan modul pelatihan dan job sheet yang berisikan gambar-gambar yang harus dikerjakan. Demonstrasi adalah metode pembelajaran dengan cara memperagakan atau melakukan suatu kegiatan dengan urutan tertentu baik secara langsung maupun menggunakan menggunakan media pembelajaran yang relevan dengan pokok bahasan materi yang sedang disajikan. Hal ini bertujuan untuk memberikan penjelasan yang lengkap dan jelas bagi para peserta dalam membuat sebuah desain. Materi yang disampaikan terangkum dalam modul pelatihan yang telah diberikan. Hasil pemahaman dan kemampuan para peserta dapat diamati dari hasil akhir desain yang telah digambar.

\section{HASIL DAN PEMBAHASAN}

Setelah mengikuti pelatihan ini peserta dapat menggunakan software SolidWorks untuk membuat desain berupa part 3D, drawing, assembly, dan animasi kinematis dari job sheet yang telah diberikan. Bertambahnya pemahaman dan skill peserta tentang manfaat software SolidWorks dalam bidang desain yang nantinya dapat diterapkan di instansi tempat peserta bekerja, khususnya bagi para siswa didiknya. Dengan tambahan materi SolidWorks ini tentunya sangat bermanfaat bagi para peserta dan siswa SMK dalam menghadapi revolusi industri 4.0.

Pemahaman terkait penggunaan software SolidWorks ini ditampilkan dari hasil kuisioner yang telah diisi oleh para peserta yang dilakukan sebelum (pre-test) dan sesudah (post-test) pelatihan berlangsung. Pre-test ini dilaksanakan dengan tujuan untuk mengetahui kondisi awal para peserta terkait pengetahuan, pemahaman, dan kemampuan dalam menggunakan software SolidWorks. Adapun hasil pre-test ini ditampilkan pada gambar 1. Setelah mengikuti pelatihan secara keseluruhan, untuk mengetahui perkembangan/peningkatan kemampuan dari para peserta maka peserta diwajibkan untuk mengisi form post-test yang telah disediakan. Hasil dari post-test ini ditampilkan pada gambar 2. Dokumentasi kegiatan pelatihan ini ditampilkan pada gambar 3.

Berdasarkan hasil kuisioner yang telah diberikan dapat diketahui bahwa setelah mengikuti pelatihan kemampuan dan pemahaman para peserta dalam mendesain menggunakan software Solidworks meningkat. Materi pelatihan yang diberikan juga mampu diserap dengan baik oleh para peserta, hal ini mengidikasikan bahwa atusias para peserta sangat tinggi dalam mengikuti pelatihan yang berlangsung. 
AbMa (Jurnal Abdi Masya): Vol. 1, No. 2, pp 66-71

Agus Jamaldi, dkk @ 2021

1. Software desain apa yang digunakan di sekolah bapak ibu saat ini?

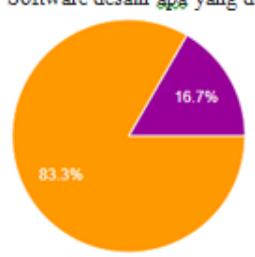

- Inventor

- Catia

- AutoCAD

- Manual

2. Apakah Anda sudah pernah menggunakan software SolidWorks sebelumnya?

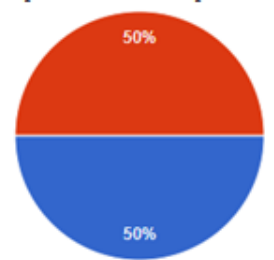

Belum

3. Apa yang Anda kuasai tentang penggunaan SolidWorks?

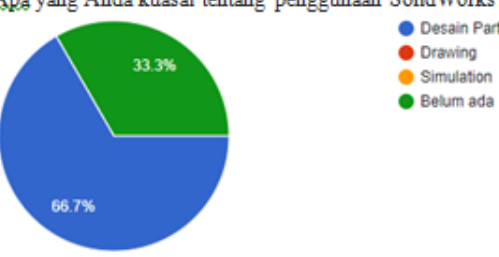

Gambar 1. Hasil pre-test

1. Menurut anda, bagaimana penyampaian materi pelatihan yang diberikan oleh instruktur?

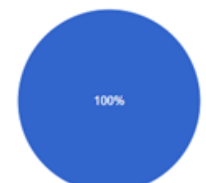

- Sangat mudah Gpanami

- Susah unbik dimengenti

2. Setelah Anda mengikuti pelatihan, apakah kemampuan/pemahaman Anda tentang SolidWorks meningkat?

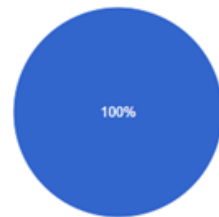

Ya, meningkat

- Belum Meningkat

3. Bagian mana yang Anda kuasai setelah mengikuti pelatihan?

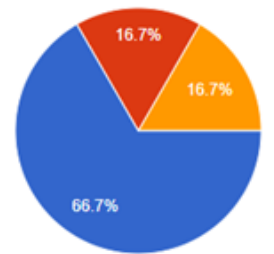

Desain Part

- Drawing

Simulation

- Belum ada

4. Apakah menurut Anda software desain sangat diperlukan dalam dunia pendidikan dan industri?

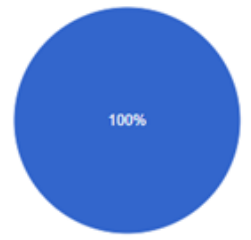

Gambar 2. Hasil post-test 

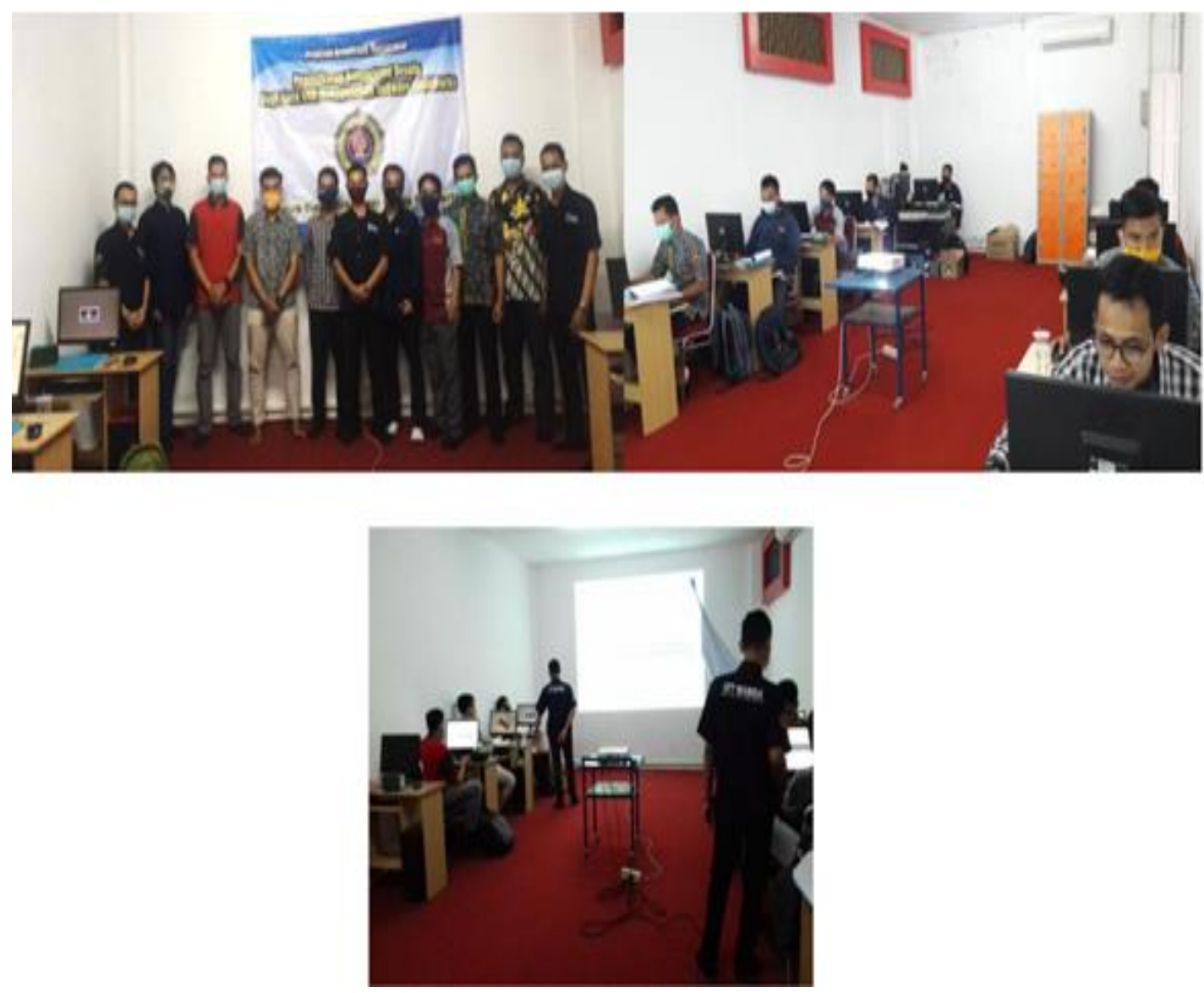

Gambar 3. Pelaksanaan pelatihan desain bagi guru-guru SMK

\section{KESIMPULAN}

Berdasarkan hasil kegiatan yang telah dilaksanakan maka dapat ditarik kesimpulan bahwa kompetensi/pengetahuan para guru SMK meningkat khususnya penggunaan software SolidWorks. Kemampuan dalam mengoperasikan software desain ini menjadi skill tambahan yang dapat ditransfer ke para siswa sehingga kedepan diharapkan para lulusan SMK memiliki kemampuan yang lebih dan siap terjun di dunia kerja.

Kegiatan semacam ini sangat diperlukan bagi para guru SMK kedepannya (ditunjukkan dari hasil kuisioner). Antusias para guru dalam mengembangkan pengetahuan dan skill perlu menjadi perhatian perguruan tinggi yang memiliki konsentrasi yang linier sebagai bukti nyata implementasi atau pelaksanaan Tridharma Perguruan Tinggi.

\section{UCAPAN TERIMA KASIH}

Ucapan terima kasih kami ucapkan kepada LPPM STT Warga Surakarta yang telah mendukung terlaksananya kegiatan PkM ini, sehingga kegiatan ini berjalan dengan lancar.

\section{DAFTAR PUSTAKA}

[1] Undang-Undang-Nomor-14-Tahun-2005. (n.d.).

[2] Permendikbud No. 34/2018 tentang Standar Nasional Pendidikan SMK/MAK. (2018). 
[3] Hermawan. (2016). Peningkatan Kompetensi Guru-Guru Smk Bidang Sains Melalui Pelatihan Sofware Engineering Di Kabupaten Wonosobo. 63-68.

[4] Teknik, T. L. C. \& G. (2016). Analisis \& Simulasi Sistem Mekanikal Dengan Software SOLIDWORKS. 1-6.

[5] Rifai. (2016). Penerapan Modul Pembelajaran Solidworks Untuk Meningkatkan Kompetensi Membuat Model 3D. Jurnal Pendidikan Teknik Mesin Unnes, 16(1), 129902. 